\section{Esophageal hematoma after peroral endoscopic myotomy for achalasia in a patient on antiplatelet therapy}
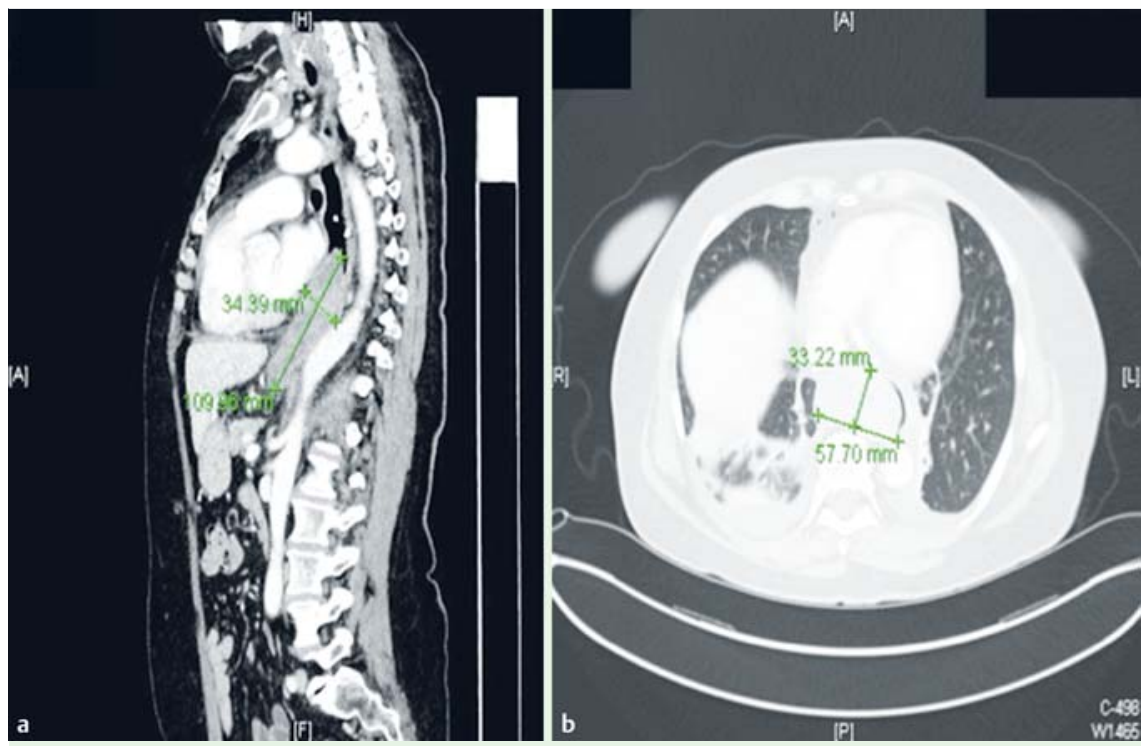

Fig. 1 X-ray computed tomography shows a hematoma of the lower part of the esophagus in a 59-year-old woman on antiplatelet therapy after she underwent peroral endoscopic myotomy (POEM) for type II achalasia. a Sagittal section. b Axial section.

Table 1 Reports of delayed bleeding after peroral endoscopic myotomy (POEM).

\begin{tabular}{|c|c|c|c|c|c|}
\hline & $\begin{array}{l}\text { Ren et al. [2] } \\
(n=119)\end{array}$ & $\begin{array}{l}\text { Li et al. [3] } \\
(n=428)\end{array}$ & $\begin{array}{l}\text { Von Renteln et al. } \\
{[4](n=70)}\end{array}$ & $\begin{array}{l}\text { IPOEMS [5] } \\
(n=841)\end{array}$ & $\begin{array}{l}\text { Our center } \\
(n=61)\end{array}$ \\
\hline $\begin{array}{l}\text { Delayed bleeding, } \\
n(\%)\end{array}$ & $1(0.8)$ & $3(0.7)$ & $2(3)$ & $8(<1)$ & $1(1.6)$ \\
\hline Hematemesis & $1 / 1$ & $3 / 3$ & NR & NR & $0 / 1$ \\
\hline $\begin{array}{l}\text { Thoracic/ } \\
\text { epigastric pain }\end{array}$ & $1 / 1$ & $1 / 3$ & NR & NR & $1 / 1$ \\
\hline $\begin{array}{l}\text { Hemoglobin } \\
\text { decrease }\end{array}$ & NR & $10-15 \mathrm{~g} / \mathrm{L}$ & NR & NR & $32 \mathrm{~g} / \mathrm{L}$ \\
\hline $\begin{array}{l}\text { Emergency } \\
\text { endoscopy }\end{array}$ & $1 / 1$ & $3 / 3$ & $1 / 2$ & NR & $0 / 1$ \\
\hline Blood transfusion & NR & $0 / 3$ & NR & $8 / 8$ & $0 / 1$ \\
\hline $\begin{array}{l}\text { Continuous anti- } \\
\text { platelet therapy }\end{array}$ & $0 / 1$ & $0 / 3$ & $0 / 2$ & $0 / 2$ & $1 / 1$ \\
\hline Sequelae & $0 / 1$ & $0 / 3$ & $0 / 2$ & $0 / 8$ & $0 / 1$ \\
\hline
\end{tabular}

IPOEMS, International Per Oral Endoscopic Myotomy Survey; NR, not reported.

Peroral endoscopic myotomy (POEM) appears to be a successful technique for the treatment of achalasia [1]. Only a few cases of delayed bleeding have been described [2]. Here, we report a case of esophageal hematoma that developed 1 day after a patient on acetylsalicylic acid (ASA) therapy underwent POEM.

A 59-year-old woman with type II achalasia was referred for a POEM procedure. She had a past history of two transient ischemic attacks, which justified continu- hematoma measuring 34 by $110 \mathrm{~mm}$ within the tunnel ( $\bullet$ Fig. 1 ), which was closed adequately by the clips.

We decided to manage this hematoma conservatively without removing the clips. At day 3, another computed tomographic scan showed a $10-\mathrm{mm}$ decrease in the hematoma. The patient's condition remained stable, and neither endoscopic hemostasis nor blood transfusion was needed. She was discharged 8 days after the procedure. Her long-term course was favorable, with total resolution of the dysphagia.

The risk-to-benefit ratio of POEM depending on various conditions is not known, especially in patients on antiplatelet therapy. Delayed bleeding after POEM is a rare adverse event. To our knowledge, very few cases have been described until now $(\bullet$ Table 1). A conservative treatment can be considered if neither blood exteriorization nor hemodynamic instability is present. Delayed bleeding does not seem to affect the long-term efficacy of the procedure. ASA may increase the risk for bleeding and should be stopped temporarily if possible. If not, the careful preventive coagulation of visible vessels in the tunnel should be performed before it is closed.

Endoscopy_UCTN_Code_CPL_1AH_2AK

Competing interests: None

\section{Nicolas Benech', Mathieu Pioche ${ }^{1,2}$, Marc O'Brien', Jérôme Rivory', Sabine Roman ${ }^{3}$, François Mion ${ }^{3}$, Thierry Ponchon ${ }^{1,2}$}

${ }^{1}$ Gastroenterology and Endoscopy Unit, Pavillon H, Edouard Herriot Hospital, Lyon, France

2 INSERM U1032, Labtau, Lyon, France ${ }^{3}$ Digestive Physiology, Hospices Civils de Lyon and Lyon I University, Lyon, France

\section{References}

1 Bhayani NH, Kurian AA, Dunst CM et al. A comparative study on comprehensive, objective outcomes of laparoscopic Heller myotomy with per-oral endoscopic myotomy (POEM) for achalasia. Ann Surg 2014; 259: 1098-1103

2 Ren Z, Zhong Y, Zhou P et al. Perioperative management and treatment for complications during and after peroral endoscopic myotomy (POEM) for esophageal achalasia (EA) (data from 119 cases). Surg Endosc 2012; 26: 3267-3272

3 Li Q-L, Zhou P-H, Yao L-Q et al. Early diagnosis and management of delayed bleeding in the submucosal tunnel after peroral endo- 
scopic myotomy for achalasia (with video). Gastrointest Endosc 2013; 78: 370-374

4 Von Renteln D, Inoue H, Minami $\mathrm{H}$ et al. Peroral endoscopic myotomy for the treatment of achalasia: a prospective single center study. Am J Gastroenterol 2012; 107: 411 417

5 Stavropoulos SN, Modayil RJ, Friedel D et al. The International Per Oral Endoscopic Myotomy Survey (IPOEMS): a snapshot of the global POEM experience. Surg Endosc 2013; 27: $3322-3338$

\section{Bibliography}

Dol http://dx.doi.org/

10.1055/s-0034-1392427

Endoscopy 2015; 47: E363-E364

(C) Georg Thieme Verlag KG

Stuttgart · New York

ISSN 0013-726X
Corresponding author

\section{Mathieu Pioche, MD}

Endoscopy Unit, Digestive Disease Department

H Pavillon, Edouard Herriot Hospital

69437 Lyon Cedex

France

Fax: +33-4-72110147

mathieu.pioche@chu-lyon.fr 